\title{
How museums, teacher educators, and schools innovate and collaborate to learn and teach Geosciences to everyone
}

\author{
Maritza Macdonald, David Silvernail ${ }^{1}$, Natasha Cooke-Nieves², Sharon Locke, Aline Fabris, Nakita Van Biene, Michael J. Passow ${ }^{3}$ \\ American Museum of Natural History, Richard Gilder Graduate School, 200 Central Park West, New York, NY 10024 \\ Center for Stem Research, Education, and Outreach, Southern lluinois University, Edwardsville, ll 62026 \\ University of Southern Maine Center for Education Policy, Applied Research and Evaluation, Portland, Maine \\ Lamont-Doherty Earth Observatory of Columbia University, New York, NY 10025

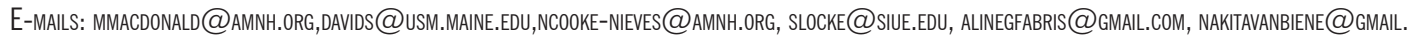 \\ COM,MICHAEL@EARTH2CLASS.ORG.
}

Abstract: Natural History museums are well known for the multiple educational opportunities they offer the public, including students, schools, and international visitors. We introduce a new role for museums: sites for the education and certification of science teachers. In 2017, the American Museum of Natural History (AMNH) completed evaluation of its initial six years as the first museum-based Master of Arts in Teaching (MAT) Earth Science program. The program was created in response to needed local and national education policies, and desire to improve Earth Science education, especially those designated 'at-risk.' This program began as a pilot program authorized by New York State. In developing museum-specific parts of the program, we included research perspectives from Learning in Informal Institutions, Spatial Thinking, and Place-Based Learning. Rigorous selection of candidates required background in one Earth Science field. Scientists, curators, and educators served as faculty. They taught courses and and directed field and laboratory experiences. MAT courses focus on learning in museums and pedagogical content knowledge regarding middle and high school Earth Science. Experiential residencies are geared toward preparing candidates to teach in museums and schools, as well as conduct independent and team science research. Courses are co-taught by scientists and educators. They are designed to incorporate museum exhibit and resources. They draw on current and past scientific research, technology, and online teaching tools to enhance instruction, demonstrate nature of science, and complement science with cultural histories that highlight the role of science in society. Evaluation evidence indicates the program has been successful in preparing teachers to teach in high-needs urban schools in New York State. The AMNH programs operate on multiple levels: graduate teaching residency program, strong partnerships with schools, provider of on-site graduate courses for other colleges, and center for research informal learning in science institutions. An external-impact quantitative study focused on student performance on standardized New York State Earth Science tests showed that students of MAT graduates do as well as students taught by other teachers with similar years of experience, and that demographically, MAT teachers instruct a higher percentage of students with lower economic and academic profiles. After Year 3, the AMNH was authorized to grant its own degrees. This paper focuses on how the program design utilizes all aspects of a natural history museum to offer the science museum community, teacher educators, and policy-makers new approaches for the preparation of teachers and the education of their students.

\section{Manuscript:}

Received: Quadrennial Conference of the International Geoscience Education Organization

Accepted: 05/06/2018

Citation: Macdonald M., Silvernail D., Cooke-Nieves N., Locke S., Fabris A., Biene N.V., Michael J. Passow M.J. 2018. How museums, teacher educators, and schools innovate and collaborate to learn and teach geosciences to everyone. Terræ Didatica, 14(3):271276. URL: http://www.ige. unicamp.br/terraedidatica/.

Keywords: Natural History Museum, Teacher Education Program, Museum Teaching and Research.

Thematic line: Teaching of Geosciences and Natural Sciences for School-Level Education and Teacher Training

\section{Introduction}

\subsection{What is the AMNH-MAT Program?}

The AMNH-MAT program is an innovative residency program designed to prepare science teachers for high need schools in metropolitan New York City (NYC) and other parts of New York.
Originally approved by the New York State (NYS) Board of Regents as part of the state's Race To The Top (RTTT) award, AMNH-MAT was designed to prepare cohorts of teacher candidates in a residency program to earn a Board of Regents-awarded Masters of Arts in Teaching (MAT) degree, with a special-ization in Earth Science for grades 7-12. The 15-month, 36-credit residency program is followed 
by two years of induction support for new teachers. In addition to a full academic year of residency in high-needs public schools, teacher candidates complete two AMNH-based clinical summer residences, one a museum teaching residency prior to entering their teacher preparation partnership schools, and the other a museum-based science practicum residency prior to graduation and entering the teaching profession. All courses are taught by teams of doctoral-level educators and scientists at the American Museum of Natural History (http://www.amnh.org).

The initial funding for this innovative museum-based residency teacher preparation program was federal RTTT funding awarded to the state of New York. In addition, AMNH was awarded a National Science Foundation DRK-12 grant to support program development and implementation, conduct on-going formative evaluation of the program over the course of the five-year grant period, and produce a summative evaluation on the impacts of the program. At that time, research evidence showed the potential of informal science organ-izations to connect schools with highly engaging science content (Dierking, Falk, Rennie, Anderson, and Ellenbogen, 2003). Through the DRK-12 program, NSF was seeking to fund projects that explored new ways to connect formal and informal learning. By conducting rigorous research on science teacher preparation in the museum context, AMNH had the opportunity to advance understanding of how the resources of informal learning institutions could be leveraged to prepare high-quality teachers for urban schools.

The AMNH-MAT program is one example of an urban teacher residency (UTR) program. There are now over 50 such programs all across the United States (Guha et al. 2017). The AMNH program is the only offered by a museum, but several of the features we discuss in this paper are being adapted by other teacher education programs interested in enriching the knowledge of the teachers they prepare by offering museum-based experiences. These UTRs are seen as innovative preparation programs designed to ex-hibit best practices in recruitment, admission, preparation, and placement of graduates in urban settings.

The AMNH-MAT program is a unique UTR firstly because the teacher preparation program has been designed and implemented by scientists, educators, and policy scholars in a major museum, and secondly because the program works in partnership with local high need urban middle and high schools, listed on the link: https://www. amnh.org/learn-teach/master-of-arts-in-teaching. The program has existed for seven years and the discusion in this paper focuses on aspects that have been evaluated, resaearched, and influenced other colleges and universities that are including museum courses and investigations with their teacher candidates.

\subsection{Program Design}

The Program consists of 36 graduate level credits and four residencies over a 15-month period (Figure 1). Acceptance to the program is selective. Candidates' academic preparation requires a bachelor's degree in one of the fields of geo-sciences, high average, and strong referenes. However, academic ranks are not enough. Can-didates also need to come with dispositions about why Earth Science is important for all, show perspectives of how this knowledge can be accomplished through education, and commit to four years of teaching.

The following three sample statements by graduates from the 2017 cohort express the types of dispositions valued for admission to the program:

"It is important for people to learn about Earth Science because we need to understand that Earth is a system and all the components need to work together in order to have a balance. It is important that we teach kids to love Earth Science because they will be the ones that will be creating policies and finding renewable energy sources. Understanding how man's interaction with the physical world works can help us make better plans and strategies to support and adapt to climate change".

"Earth Science presents an opportunity to create an exciting and entirely human connection with our world, filled with wonder, adventure, and discovery. Every time my students study dirt under a microscope, compare a granite's minerals to a sandstone's, or hunt for a fossil in the field, I want them to think about where it's been, the story it tells, the ways humanity affected it, and the ways it affects humanity. Rocks shape society, and in recent geological time, society shapes rocks. Young people deserve an engaging Earth Science education, not only to spark their critical thinking and problem solving skills, but also to prepare them to use those skills to tackle environmental issues as they enter adulthood." 
"With the knowledge found in the Earth Science field, you can teach people how their everyday choices impact the Earth, and give people the tools to make considerate decisions for our environment. These changes to people's micro decisions could eventually spread to the macro, through green legislation and environmental requirements. One of the ways we can mitigate our changing climate is by educating citizens regarding how our planet works. Through educating people about our Earth we can continue to improve and make our habitat better. At least until space travel improves."

The key museum-based program structures we discuss in this paper are (1) the museumbased-teaching and quaitative research project in summer 1, (2) the museum Science investigations by students during the first academic semestre, and (3) the field and laboratory practicum with museum scientists and curators during summer 2 , at the end of the program. In terms of academic structures, all science courses are co-taught by scientists and educators, and pedagogical courses include a specialists and a practitioner, all instructors use the museum resources, programs, and technological resources where it facilitates their teaching. In this paper we focus on three of the most museum education and scientific research dimensions of the museum in the contexts of the MAT. Summer 1 Museum teaching residency and EDU 600, School Science investigations at the museum for EDU 610, and the Research Practicum in Summer 2, that offers 10 weeks of fied and laboratory work with museum scientists and curators. The program has undergone a full external evaluation and impact research study funded by the National Science Foundation (NSF). All aspects of this paper have been part of the evaluation process outlined in the following findings documented by the University of Southern Maine's Center for Education Policy, Applied Research and Evaluation (D. Silvernail).

The evaluation evidence reveals that one of the major strengths of the MAT program is the level of instruction the candidates receive over the course of the program. As part of the external evaluation, each course was evaluated by the candidates at the end of the course, and this data was used by the project PIs and faculty to make improvements in the content and delivery of both the science and education courses, both of which were co-taught. The end-of-course evaluation surveys, completed by the candidates, were

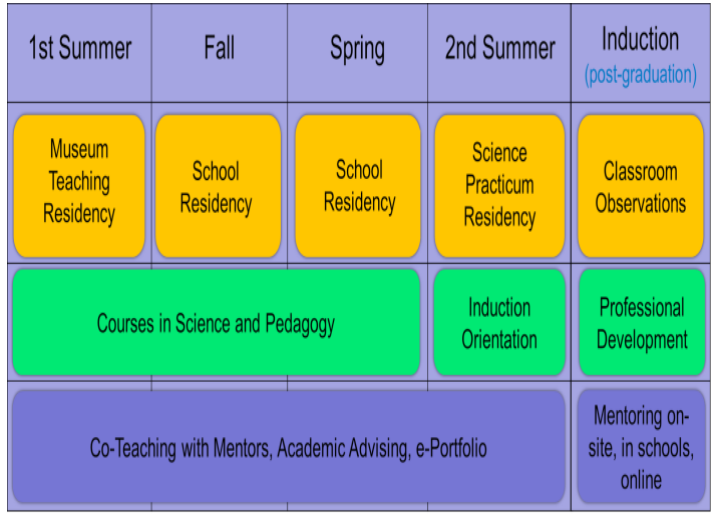

Figure 1. Program schedule for AMNH-MAT

designed to provide assessments in four key areas. The four areas were:

Course organization. This cluster of items focused on assessing how well the courses were organized, and how well course objectives were met. The effectiveness of the co-teaching model was also assessed.

Course work and assignments. These items assessed the usefulness of the reading assignments, materials and course work in contributing to their understanding of the subject and in helping them learn how to become a better science teacher.

Museum resources. How well the instructors integrated the use of the Museum and its resources into the course, and how well the Museum environment contributed to the candidates' understanding were assessed by this set of items.

Student-centered approach. The fourth cluster assessed how responsive the instructors were to candidate questions and comments and how well they apply the course content and concepts in their residencies.

\section{Museum-focused Program Components}

\subsection{Summer 1: Informal Learning, Teaching, and Researching at the Museum}

The most immersive museum-centered experiences are designed to occur in Summer 1 and Summer 2, and in an academic course during the school-based residency from September to January. Summer 1 (June-August), focuses on learning to teach urban adolescent students and develop abilities to use collections, teaching carts, and scientific tools with visitors in informal settings (Fig. 2). All practices are framed by academic 
and theoretical courses (theory-practice). Summer 1 includes the practicum and, two academic courses that focus on the pedagogy and research for learning in Informal Science Settings (National Research Council 2009); and Qualitative research skills. These foundational courses and practicum prepares candidates to be keen observers of students, understand the topics of adolescent development, and be able to document their observations of students and mentor teachers to consider pedagogical strategies that are required. Informal Science pedagogical approaches focus on students' intrinsic goals and interests, using tools of investigation, scientific reasoning, clarifying content and concept knowledge, and development of an identity as critical thinkers. The two other fields of pedagogical research that support the summer and the future courses are Place-Based Learning (Semken \& Freeman 2008) and Spatial Thinking (Kastens et al. 2014).

This heavy immersion into the museum as a place for learning and teaching science aims at preparing candidates to be the "teaching in museum experts" when they enter the schools in September, when they will plan and implement an investigation with students in their residency schools. MAT faculty members and teacher practitioners who teach in summer camps and programs, and use Museum resources, including collections, exhibitions, media, and online resources, are the mentors, instructors, and scientists (Gupta et al. 2017).

\subsection{Museum Science Investigations}

From September to June, candidates complete

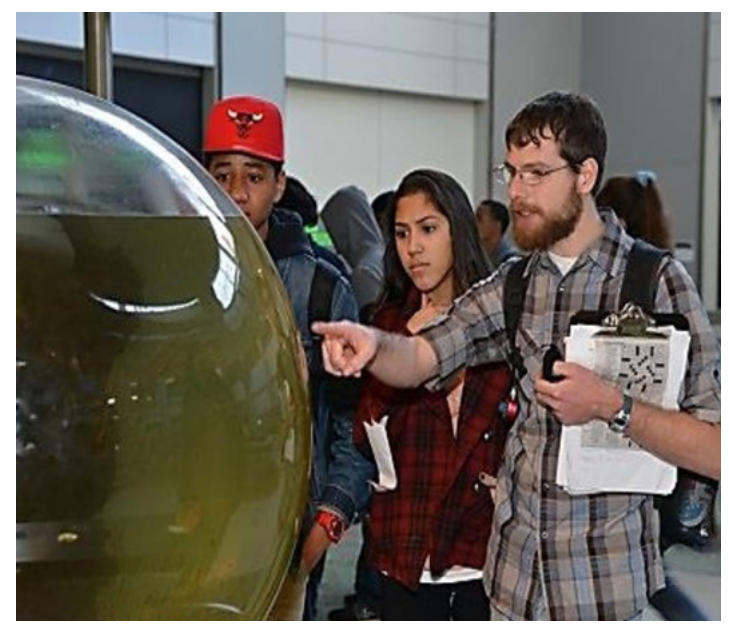

Figure 2. Museum visitors learning from MAT graduate two public school residencies. At schools, they are mentored by science teachers and museum faculty; They are in schools for five months at each residency four days a week. They rotate between the assigned Science mentor, and classrooms with students who are new English language learners. During the candidates' first school residency (from September to December), they take a course titled EDU 610, "Literacy in Content Area with Applications to Multilingual Contexts," which is intended to emphasize the literacy skills for Science learning and learn to use multiple literacy opportunities outside school at a science rich setting in a well crafted museum-based Science investigation.

This experience provides multiple scaffolds for reading, writing, and understanding from exhibition labels, and for using and visual, tactile, three dimensional, and interactive opportunities that make Earth and Space Science more accessible to all students, and in particular for schools with large populations of new immigrant student who come with knowledge of their own contexts and geographies but who are learning English for the first time (Macdonald et al. 2016). Each teacher candidate designs a rationale, a plan, and complete and assessment rubric with some of the following items.

1. "The teacher understands the central concepts of the discipline he or she teaches during the museum investigation and can make the subject matter meaningful to students (Strands 1, 2 and 3ISE and in-school curriculum focus)"

2. "The teacher understands how students differ in their approaches to learning and creates instructional opportunities that are adapted to diverse learners. The teacher understands how students differ in their literacy and English language levels. He or she develops an investigation plan that scaffolds models, for multiple modes of communication such as drawing, conversational aspects of the trip, specified label copied information, sentence completion, creative responses, and accepts student's work in their native or bilingual language levels"

The investigations supplement the schoolbased curriculum and reinforce the partnership aspects of the AMNH and residency schools. A sample rationale statement for an investigation follows: 


\section{What is the academic focus of the investigation? How will the investigation complement the in-school curriculum?}

\begin{abstract}
Students are in two different seventh-grade science classes: students in the 7.1 class are in Earth Science and students in 7.2 are in General Science. The academic focus of the investigation is the Rocks and Minerals unit of the Earth Science core curriculum (ES Unit 3 on NYC 6-12 Science Scope \& Sequence) and the Energy and Matter unit of the seventh-grade science curriculum (Grade 7 Unit 2 on NYC 6-12 Science Scope \& Sequence).
\end{abstract}

School teachers and mentors are involved in the planning and in teaching candidates about the policies and procedures for taking students outside the schools. At the end of the investigations candidates have learned to teach curriculum aspects at the museum, assess student work done at the museum, and assess student interests based on their questions. In terms of the museum-school relationships, school principals are considered Clinical Faculty of the program, they participate in Faculty meetings, in decisions for identifying mentors, and in reviewing program documents. More than 800 students participate in the investigations each year.

A program video was featured in the New York Times: https://www.nytimes.com/video/opinion/100000002602875/teaching-science-teachers. html

\subsection{Research Practicum: Summer 2}

During the second summer, Residents undertake a seven-week AMNH-based science practicum (SCI 680 Science Research Practicum) under the supervision of a faculty member, including curators and postdoctoral fellows. The practicum's objective is to help Residents develop firsthand knowledge of the practice of science through a variety of methods, including fieldwork expeditions, investigations in laboratory settings, and engagement in secondary research methods. The practicum exposes Residents to key concepts, scientific questions, tools, and techniques, and enables them to experience and implement selected learning activities that align with state and national standards and are relevant to the practices of science explored during the practicum.

Residents spend two of the seven weeks learning and teaching in the field in the greater New
York City metropolitan area (Fig. 3). Examples include investigating metamorphic rocks and evidence of past glaciation in Central Park; exploring landscapes and soil formation near the Black Rock Forest in Cornwall, New York; and searching for and characterizing fossils from the late Cretaceous in Monmouth, New Jersey (download the Hernshead Field Guide created by graduates of the MAT program in 2016). They also spend time under the supervision of Museum curators and postdoctoral fellows using a variety of laboratory-based tools to collect and analyze Earth Science data. As Residents experience firsthand collecting and analyzing Earth Science data, they also work with Museum faculty to access, learn about, and teach with the broad range of freely available Earth Systems data sets. These experiences are combined with digital resources, enabling Residents to explore more generally the nature and practice of Earth and space Science Each Resident develops a teaching resource based on their research in the practicum. They also formally present to the Museum community about their summer research (Ebel et al. 2015).

\section{Conclusions and Applications}

In summary, this paper is designed to provide the field of Geoscience education strategies and approaches to create program innovations and partnerships to genuinely and formally bring informal institutions and scientific field experience to teachers and their students. The second most important scientific contribution is to offer models by which research scientists extend their preparation to education departments and their teacher candidates.

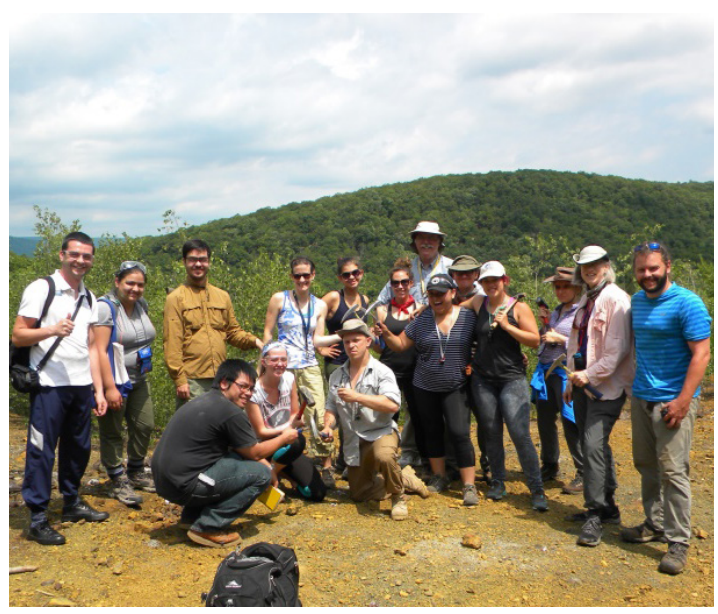

Figure 3. Regional field investigation by MAT students 
One collaborative structure has been to infuse Informal Science learning through courses at other teacher education institutions. At present, four institutions of teacher preparation in NYC contract for required courses taught at the museum by authors, and designed specifically to meet the needs of their teacher candidates and programs. For example, the AMNH course "Informal Science" for Columbia Teacher's College is designed for candidates in multiple programs such as Early Childhood, Science for secondary schools, Cognitive Sciences, and Technology. "Museum Resources for Teaching Secondary Sciences" for Lehman College (CUNY), focuses on new teachers preparing to be certified in science. "Science in the City" for Barnard College, is designed for undergraduates in Science who are considering applying to graduate school for science teaching; and a course for Bank Street College has been designed to supplement science requirements to enter teacher education. Most courses include the planning and implementation of museum investigations because it provides empirical experiences for teacher candidates and their students.

Reflections of MAT graduates can be viewed at the site https://youtu.be/dq4P9TR_aUA.

\section{Acknowledgements}

This work was supported in part by the National Science Foundation under Grant Number 1119444 and the U.S. Department of Education under Grant Number U336S140026.

\section{References}

Dierking L.D., Falk J.H., Rennie L., Anderson D., Ellenbogen K. 2003. Policy statement of the "informal science education" ad hoc committee. J. Res. Sci. Teaching, 40(2):108-111.
Ebel D., Kinzler R., Harlow G., Webster J., Sessa J., Nadeau P., Ustunisik G. 2015. Field and lab practicum provides tools to inspire geoscience classroom learning. Geol. Soc. Am. Abstracts with Programs, 47(7):190.

Guha R., Hyler M.E., Darling-Hammond L. 2017. The teacher residency: A practical path to recruitment and retention. American Educator, 41(1):31-34.

Gupta P., Trowbridge C., and Macdonald, M. 2016. Breaking dichotomies: Learning to be a teacher of science in formal and informal Settings. Chapter in Intersections of Formal and Informal Science. Avraamidou, L. and Roth, W-M., eds. (Routledge Research in Education April 2016).

Kastens K., Pistolesi L., Passow M.J. 2014. Analysis of spatial concepts, spatial skills, and spatial representations in NY State Regents Earth Science Examinations. J. Geosc. Educ., 62(2):278-289.

Macdonald M. 2015. Why and How Cultural Institutions Need to be Included in the Preparation of Teachers. Keynote Presentation and Pre-conference Workshop at the International Congress on Education for the Future: Issues and Challenges, University of Ankara, Turkey, May 13-15, 2015.

Macdonald M., Altman R., Holmes J. (In Review). Learning to Teach Newcomer Students Using Dioramas of North America.

National Research Council 2009. . Learning Science in Informal Environments: People, Places, and Pursuits. Committee on Learning Science in Informal Environments. P. Bell, B. Lewenstein, A.W. Shouse, M.A. Feder. eds. 2009. Center for Education, Division of Behavioral and Social Sciences and Education. Washington, DC: The National Academies Press.

Semken S., Freeman C.B. 2008. Sense of place in the practice and assessment of place-based science teaching. Wiley Periodicals, Inc. Sci. Ed., 92:10421057.

Ustunisik G.K., Zirakparvar N.A. 2015. A museumbased urban teacher residency program's approach to strengthening the STEM pipeline: Channeling highly qualified Earth Science teachers into high needs schools. In: AGU Fall Meeting Abstracts, December 2015

Zirakparvar N.A. 2015. A balancing act in third space: Graduate-level earth science in an urban teacher-residency program. J. Geosc. Educ., 63(3):167175. 